\title{
THE EFFECT OF INDUSTRIAL AIR POLLUTION ON MEMBRANE LIPID COMPOSITION OF SCOTS PINE (PINUS SYLVESTRIS L.) NEEDLES
}

\author{
PAWE⿺ M. PUKACKI \\ Institute of Dendrology, Polish Academy of Sciences \\ Parkowa 5, 62-035 Kórnik, Poland \\ e-mail: ppukacki@man.poznan.pl
}

(Received: January 2, 2004. Accepted: September 2, 2004)

\begin{abstract}
This work was undertaken to determine lipids changes in needles of Scots pine (Pinus sylvestris L.) populations growning on polluted stands near a phosphate fertilizer factory in Luboń, and copper smelter in Głogów and in a control area in Kórnik. Needles from polluted areas had a lower content of total phospholipids than samples from the unpolluted site. Greater changes were detected in membranes of needles collected in October and January. In comparison with the control total phospholipid in needles of populations from polluted areas were 14 to $33 \%$ lower. Phosphatidylcholine (PC) phosphatidylethanolamine (PE) and phosphatidylglicerol (PG) were the dominant phospholipids. The analysis of fatty acids in phospholipid fraction showed a decrease of linoleic acid (18:2) and linolenic acid (18:3) contents. The level of polyunsaturated fatty acids in needles of three populations from polluted areas was up to $40 \%$ lower as compared with the control. Moreover, phospholipids and their fatty acids showed seasonal fluctuations. The contents of PC, PG and PE increased in autumn and in winter, during the process of cold acclimation. In July, current-year needles did not show significant differences in membrane lipid composition between the polluted areas of Scots pine populations. The results suggest that the lipid changes of needles could be associated with disturbances in phohospholipid metabolism, caused by environmental pollution.
\end{abstract}

KEY WORDS: air pollution, fatty acids, heavy metals, phospholipids, $\mathrm{SO}_{2}$.

\section{INTRODUCTION}

In industrial areas air and soil pollutants can have detrimental effects on the physiology of north temperate conifer species, with immediate consequences for vitality and plant production (Nilsson 1991). Scots pine needles are often exposed to direct or indirect effects of industrial pollution for a long time. During those long periods they may strongly interact with other abiotic factors like low temperatures, or drought stress, which lead to changes in cellular level of membrane structures, or formation of free radicals in different compartments of the needle cell (Pukacki and Kamińska-Rożek 2003). For example, an increased sensitivity to freezing temperatures was observed in needles of Sitka spruce (Picea sitchensis) following exposure to low concentrations of $\mathrm{SO}_{2}+\mathrm{NO}_{2}$ (Freer-Smith and Mansfield 1987). The content and composition of lipids are closely related to frost and drought tolerance of coniferous plants (Sutinen et al. 1992; Taulavuori et al. 1996). The needles plasma membrane or/chloroplasts are the first compartment that comes into contact with air pollutants. On the other hand, it is well known that lipids affect the structure and function of membranes, e.g. biophysical properties (membrane phase transitions, fluidity, viscosity and permeability), and enzyme activities (Leshem 1992). Chloroplasts contain and synthesise approximately $75 \%$ of total leaf lipids. In the previous study (Pukacki 2000) it was found that Scots pine needles exposed to a long-term air and soil pollution indicated significant differences in photochemical efficiency of photosystem II as compared to control. The photosynthetic reactions, both electron transport as well as $\mathrm{CO}_{2}$ assimilation are of primary interest in the context of the toxic effects of heavy metals and toxic gases on plants. Fluoride caused a decrease in content of fatty acids in Pinus banksiana (Zwiazek and Shay 1988). There is some information about the effects of air pollutant on membrane needles in conifers, generally from experiments, which were done on seedlings or young trees grown under control cabins (Wingsle and Hällgren 1993; Tomaszewska et al. 1996), but little is known about a long-term effect of open-field exposure systems.

In the present study we examined seasonal changes in the lipid composition and its pattern of Scots pine needles collected from two polluted and control sites. The plant material for our investigations came from three experimental trials of Scots pine trees including 3 European prove- 
nances, growing in Luboń, close to a phosphate fertiliser factory, in Głogów, close to a copper foundry, and in Kórnik, a region free of acute pollution levels. The full characteristic of experimental areas and soil chemical properties of the three sites were presented earlier by Oleksyn et al. (1999).

\section{MATERIAL AND METHODS}

\section{Plant material}

Needle samples were collected from 17-year-old Scots pine (Pinus sylvestris L.), trees representing three populations: No. 3 (Russia) 58 46', No. 8 (Poland) $51^{\circ} 08^{\prime}$ and No. 16 (Slovakia) 48 46', as described previously (Oleksyn et al. 1992; Pukacki 2000). Each population was represented by three trees. The same populations of Scots pine grew in three areas: Kórnik - control site, Luboń, $2 \mathrm{~km}$ from the phosphate fertiliser factory, and Głogów, $4 \mathrm{~km}$ from the copper foundry. Populations from contaminated area Luboń were influenced for many years by high concentrations of $\mathrm{SO}_{2}$, about $445 \mathrm{t} \mathrm{yr}^{-1}$ and fluor compounds calculated as $\mathrm{F}$ equivalents, about $18.4 \mathrm{t} \mathrm{yr}^{-1}$ (Reich et al. 1994). In $1990 \mathrm{HF}$ production was suspended, stopping fluoride emissions (Anonymous, 1991). A few years ago the emission of $\mathrm{SO}_{2}$ was also markedly reduced, but the effects of acid rain in the soil, such as high concentration of aluminium ions and low $\mathrm{pH}$, are still present (Reich et al.1994). Populations from Głogów are influenced up to this time by high concentrations of $\mathrm{Cu}, \mathrm{Zn}$ and $\mathrm{Pb}$ ions in the soil, and $\mathrm{SO}_{2} \mathrm{NO}_{x}$ and $\mathrm{H}_{2} \mathrm{~S}$ in the air (Knop et al. 1998; Prus-Głowacki et al. 1999; Pukacka and Pukacki 2000a, b). Samples were taken from branches at the same height, from the same side of the tree. After collection, the twigs were transported to the laboratory in sealed plastic bags, placed into thermos. In the laboratory the twigs were stored at $2^{\circ} \mathrm{C}$ until use.

\section{Lipid analysis}

The samples (5 g each) of needles were ground to powder in liquid nitrogen and lipids were extracted with chlorophorm:methanol $(2: 1, \mathrm{v} / \mathrm{v})$, according to Kendall and McKersie (1989) and Pukacki and Rożek-Kamińska (2002). The separation of polar and non polar lipids was performed using SEP-PAK Silica cartridge (Waters) (Juaneda and Rocquelin 1985). Phospholipids were fractionated by TLC on silica gel, 60 plates, in chloroform:methanol:acetic acid:water (85:15:10:3.5, v/v, (Nichols et al. 1965). Classes of phospholipid were identified and determined as inorganic Pi according to the method of Ames (1966). Quantities of the particular phospholipids were

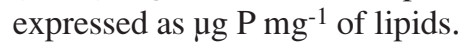

Total fatty acids methyl esters were determined in an aliquot of the phospholipid fraction according to Kendall and McKersie (1989), and Pukacki et al. (1991). Fatty acids were methylated by $14 \% \mathrm{BF}_{3}$ in methanol and quantified by gas chromatograph (Hewlett Packard, Model 5890), at temperature increase programmed between $160^{\circ}$ and $280^{\circ} \mathrm{C}$ at $5^{\circ} \mathrm{C} \mathrm{min}{ }^{-1}$. Fatty acids were quantified and identified by comparison of retention times using methylheptadecanoate (C17) (Sigma) as internal standard.

\section{Statistical analysis}

All data were examined statistically by using the oneway analysis of variance (ANOVA) for each parameter. When the effect was significant $(P<0.05)$, differences between means were evaluated for significance by using Duncan's a multiple range test.

\section{RESULTS AND DISCUSSION}

The extensive natural geographic range of Scots pine results in a great genetic variability of many traits of this species (Giertych 1993). The studied provenances derive from distant geographic regions. They differ in morphological traits, mean tree height, shoot length and needle biomass (Fober 1997). Irrespective of differences between provenances, the trees growing on the polluted plot at Lubon generally have a lower needle biomass, as compared with the control plot at Kórnik (Fober 1997). The trees of Polish provenance (Rychtal) produced the longest needles. Significant differences were also detected in concentration of some elements in pollen and needles of trees of the studied provenances. The concentration of toxic heavy metals was higher in tissues developed on the polluted plot (Reich et al. 1994; Oleksyn et al. 1999; Prus-Głowacki et al. 1999).

The total concentration of phospholipids, which are basic components of cellular membranes, was significantly lower in needles of pine trees growing within the buffer zone of the Phosphorus Fertilizer Works at Lubon and Copper Works at Głogów, as compared to the control trees growing at Kórnik (Fig. 1). In all plots, an increasing trend of phospholipid concentration was observed in the analysed pine needles in autumn, which is characteristic for woody plants of the temperate zone. This is related to metabolic changes associated with the onset of winter dormancy, preparing the plants to the low temperature stress. It is characteristic that the largest differences between needle samples of the studied populations can be observed in the case of two phospholipids that account for $50 \%$ of the weight of cytoplasmic membranes in Scots pine needles: phosphatidylcholine (PC) and phosphatidylinositol (PI) (Table 1). In January, the total concentration of phospholipids in needles from the polluted plot (Luboń) was 5-23\% lower than in needles from the control plot (Kórnik). Similar differences were found during autumn and winter seasons between the quantum yield of PSII electron transport after open-field fumigation

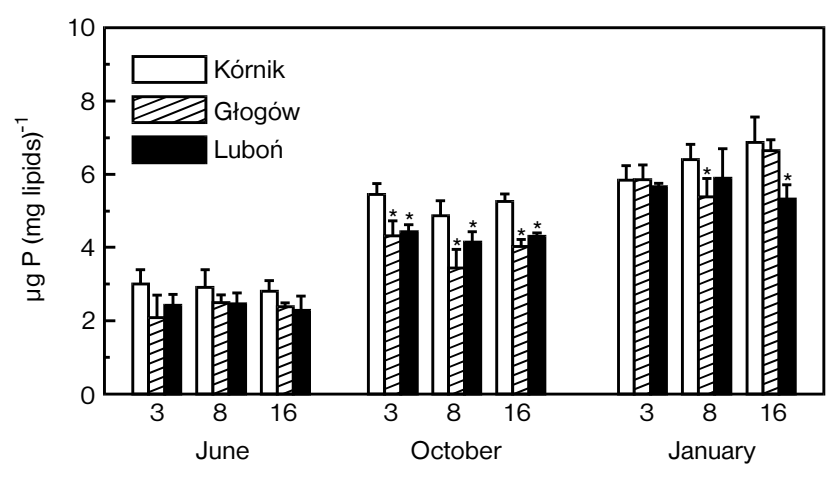

Fig. 1. The seasonal changes of total phospholipids content in needles of three Scots pine populations growing in Kórnik (control), Głogów and Luboń (polluted sites). Values are mean from three trees $(n=6) \pm S D$. Significance between control and polluted, at $* P<0.05$. 
TABLE 1. Effect of long-term pollution stress on the content and composition of phospholipid in needles of Scots pine three populations from three sites, differing in the type and intensity of air/soil pollution (Głogów, Luboń) and control (Kórnik). Mean followed by the same letter did not differ significantly $(P<0.05$, ANOVA, Duncan's multiple range test.

\begin{tabular}{|c|c|c|c|c|c|c|c|c|}
\hline \multirow{2}{*}{ Month } & \multirow{2}{*}{$\begin{array}{c}\text { Population } \\
\text { No. }\end{array}$} & \multirow{2}{*}{ Site } & \multicolumn{6}{|c|}{ Phospholipid ( $\mu \mathrm{g} \mathrm{mg}^{-1}$ lipids) } \\
\hline & & & PI & $\mathrm{PC}$ & PG & PE & PA & $\mathrm{PC} / \mathrm{PE}$ \\
\hline \multirow[t]{12}{*}{ June } & 3 & Kórnik & $0.36 \mathrm{a}$ & $1.65 \mathrm{a}$ & $0.54 \mathrm{a}$ & $0.42 b$ & $0.22 \mathrm{a}$ & $4.1 \mathrm{a}$ \\
\hline & & Głogów & $0.14 \mathrm{c}$ & $1.62 \mathrm{a}$ & $0.27 \mathrm{c}$ & $0.66 \mathrm{a}$ & $0.19 \mathrm{a}$ & $2.4 \mathrm{c}$ \\
\hline & & Luboń & $0.30 \mathrm{ab}$ & $1.54 \mathrm{ab}$ & $0.41 \mathrm{ab}$ & $0.40 \mathrm{~b}$ & $0.09 \mathrm{~b}$ & $3.7 \mathrm{ab}$ \\
\hline & 8 & Kórnik & $0.54 \mathrm{a}$ & $1.86 \mathrm{a}$ & $0.59 \mathrm{a}$ & $0.43 b$ & $0.35 \mathrm{a}$ & $4.3 \mathrm{a}$ \\
\hline & & Głogów & $0.10 \mathrm{c}$ & $1.43 b$ & $0.22 \mathrm{c}$ & $0.50 \mathrm{a}$ & $0.14 b$ & $2.8 \mathrm{c}$ \\
\hline & & Luboń & $0.26 \mathrm{~b}$ & $1.57 \mathrm{~b}$ & $0.43 \mathrm{ab}$ & $0.48 \mathrm{a}$ & $0.19 b$ & $3.2 b$ \\
\hline & 16 & Kórnik & $0.34 \mathrm{a}$ & $1.61 \mathrm{a}$ & $0.51 \mathrm{a}$ & $0.40 \mathrm{~b}$ & $0.22 \mathrm{a}$ & $4.0 \mathrm{a}$ \\
\hline & & Głogów & $0.05 c$ & $1.70 \mathrm{a}$ & $0.25 \mathrm{c}$ & $0.61 \mathrm{ab}$ & $0.20 \mathrm{a}$ & $2.8 \mathrm{bc}$ \\
\hline & & Luboń & $0.21 \mathrm{~b}$ & $1.54 \mathrm{ab}$ & $0.36 \mathrm{~b}$ & $0.41 b$ & $0.12 b$ & $3.4 \mathrm{~b}$ \\
\hline & Mean* & Kórnik & 0.41 & 1.70 & 0.54 & 0.42 & 0.26 & 4.1 \\
\hline & & Głogów & 0.09 & 1.58 & 0.24 & 0.59 & 0.17 & 2.7 \\
\hline & & Luboń & 0.25 & 1.55 & 0.40 & 0.43 & 0.12 & 3.4 \\
\hline \multirow[t]{12}{*}{ October } & 3 & Kórnik & $0.57 \mathrm{a}$ & $2.50 \mathrm{a}$ & $0.81 \mathrm{a}$ & $0.64 b$ & $1.18 \mathrm{a}$ & $3.9 \mathrm{a}$ \\
\hline & & Głogów & $0.40 \mathrm{~b}$ & $2.42 \mathrm{ab}$ & $0.56 \mathrm{~b}$ & $0.86 \mathrm{a}$ & $0.28 b$ & $2.8 \mathrm{~b}$ \\
\hline & & Luboń & $0.48 \mathrm{a}$ & $2.23 c$ & $0.18 \mathrm{c}$ & $0.64 b$ & $1.18 \mathrm{a}$ & $3.9 \mathrm{a}$ \\
\hline & 8 & Kórnik & $0.60 \mathrm{a}$ & $2.84 \mathrm{a}$ & $0.64 \mathrm{a}$ & $0.62 \mathrm{a}$ & $1.20 \mathrm{a}$ & $4.6 \mathrm{a}$ \\
\hline & & Głogów & $0.33 b c$ & $1.90 \mathrm{~b}$ & $0.49 b$ & $0.64 \mathrm{a}$ & $0.21 \mathrm{c}$ & $2.9 \mathrm{~b}$ \\
\hline & & Luboń & $0.45 b$ & $2.11 \mathrm{~b}$ & $0.11 \mathrm{c}$ & $0.54 \mathrm{a}$ & $0.84 b$ & $3.9 \mathrm{a}$ \\
\hline & 16 & Kórnik & $0.49 \mathrm{a}$ & $2.50 \mathrm{a}$ & $0.65 \mathrm{a}$ & $0.87 \mathrm{a}$ & $1.14 \mathrm{a}$ & $3.7 \mathrm{~b}$ \\
\hline & & Głogów & $0.34 \mathrm{c}$ & $2.26 \mathrm{~b}$ & $0.55 b$ & $0.82 \mathrm{a}$ & $0.24 \mathrm{c}$ & $2.7 \mathrm{c}$ \\
\hline & & Luboń & $0.40 \mathrm{~b}$ & $2.45 \mathrm{a}$ & $0.07 \mathrm{c}$ & $0.53 b$ & $0.99 \mathrm{ab}$ & $4.6 \mathrm{a}$ \\
\hline & Mean & Kórnik & 0.55 & 2.61 & 0.70 & 0.71 & 1.17 & 4.1 \\
\hline & & Gtogów & 0.35 & 2.18 & 0.53 & 0.77 & 0.24 & 2.8 \\
\hline & & Luboń & 0.44 & 2.26 & 0.09 & 0.55 & 0.94 & 4.1 \\
\hline \multirow[t]{12}{*}{ January } & 3 & Kórnik & $0.84 \mathrm{a}$ & $2.94 \mathrm{ab}$ & $1.01 \mathrm{a}$ & $1.28 \mathrm{a}$ & $0.71 \mathrm{a}$ & $2.3 \mathrm{~b}$ \\
\hline & & Głogów & $0.78 b$ & $3.32 \mathrm{a}$ & $1.09 \mathrm{a}$ & $1.27 \mathrm{a}$ & $0.73 a$ & $2.6 \mathrm{a}$ \\
\hline & & Luboń & $0.50 \mathrm{c}$ & $2.68 \mathrm{c}$ & $0.60 \mathrm{~b}$ & $1.21 \mathrm{ab}$ & $0.28 b$ & $2.2 \mathrm{~b}$ \\
\hline & 8 & Kórnik & $0.79 a$ & $3.43 \mathrm{a}$ & $1.00 \mathrm{a}$ & $1.62 \mathrm{a}$ & $0.46 \mathrm{~b}$ & $2.1 \mathrm{~b}$ \\
\hline & & Głogów & $0.66 b$ & $3.03 \mathrm{c}$ & $0.86 \mathrm{~b}$ & $1.41 \mathrm{~b}$ & $0.60 \mathrm{a}$ & $2.1 \mathrm{~b}$ \\
\hline & & Luboń & $0.65 b$ & $3.36 \mathrm{ab}$ & $0.97 \mathrm{a}$ & $1.15 \mathrm{c}$ & $0.28 \mathrm{c}$ & $2.9 \mathrm{a}$ \\
\hline & 16 & Kórnik & $0.74 b$ & $3.07 \mathrm{~b}$ & $0.95 \mathrm{a}$ & $1.42 \mathrm{~b}$ & $0.33 b$ & $2.1 \mathrm{~b}$ \\
\hline & & Głogów & $0.97 \mathrm{a}$ & $3.82 \mathrm{a}$ & $1.03 \mathrm{a}$ & $1.58 \mathrm{ab}$ & $0.55 \mathrm{ab}$ & $2.4 \mathrm{a}$ \\
\hline & & Luboń & $0.25 \mathrm{c}$ & $1.97 \mathrm{c}$ & $0.64 b$ & $0.82 \mathrm{c}$ & $0.11 \mathrm{c}$ & $2.4 \mathrm{a}$ \\
\hline & Mean & Kórnik & 0.79 & 3.14 & 0.98 & 1.44 & 0.50 & 2.2 \\
\hline & & Głogów & 0.80 & 3.39 & 0.99 & 1.42 & 0.62 & 2.4 \\
\hline & & Luboń & 0.46 & 2.67 & 0.73 & 1.06 & 0.22 & 2.5 \\
\hline
\end{tabular}

*Means for tree sites: control (Kórnik), pollution (Głogów and Luboń)

PI - phosphatidylinositol; PC - phosphatidylcholine; PG - phosphatidylglycerol; PE - phosphatidylethanolamine; PA - phosphatidic acid

$\mathrm{SO}_{2}+\mathrm{NO}_{2}$ of Pinus sylvestris needles (Strand 1995). Earlier research showed that a high PC concentration is characteristic for plants better prepared to cope with abiotic stress factors, such as low temperatures (Yoshida and Uemura 1990). A sufficiently high PC concentration allows cells to control properly the selective permeability of membranes to ions and water. When comparing the total concentration of phospholipids in needles representing three provenances of Scots pine, it can be noticed that needles of the Russian provenance (Serebryanskoye) are in a better physiological condition than needles of the Polish (Rychtal) and Slovakian (Zahorie) provenances (Fig. 1). The concentration of phospholipids, especially PC, decreases by about $20 \%$ in seedlings of Pinus banksiana also under the influence of a 2-day treatment with fluorine (Zwiazek and Shay 1988). Structural changes in cytoplasmic membranes in Scots pine needles exposed to the activity of $\mathrm{SO}_{2}$ cause degradation of triglycerides and an increase in amount and size of lipid bodies in chloroplast membranes (Anttonen 1992). Thus it can be assumed that the degradation of lipid structures of cytoplasmic membranes in Scots pine needles in polluted habitats starts as early as in spring, during development of needle primordia. The needles formed in a polluted environment may have a markedly lower tolerance to other abiotic stress factors, as compared with needles developed in areas free from heavy pollution. 


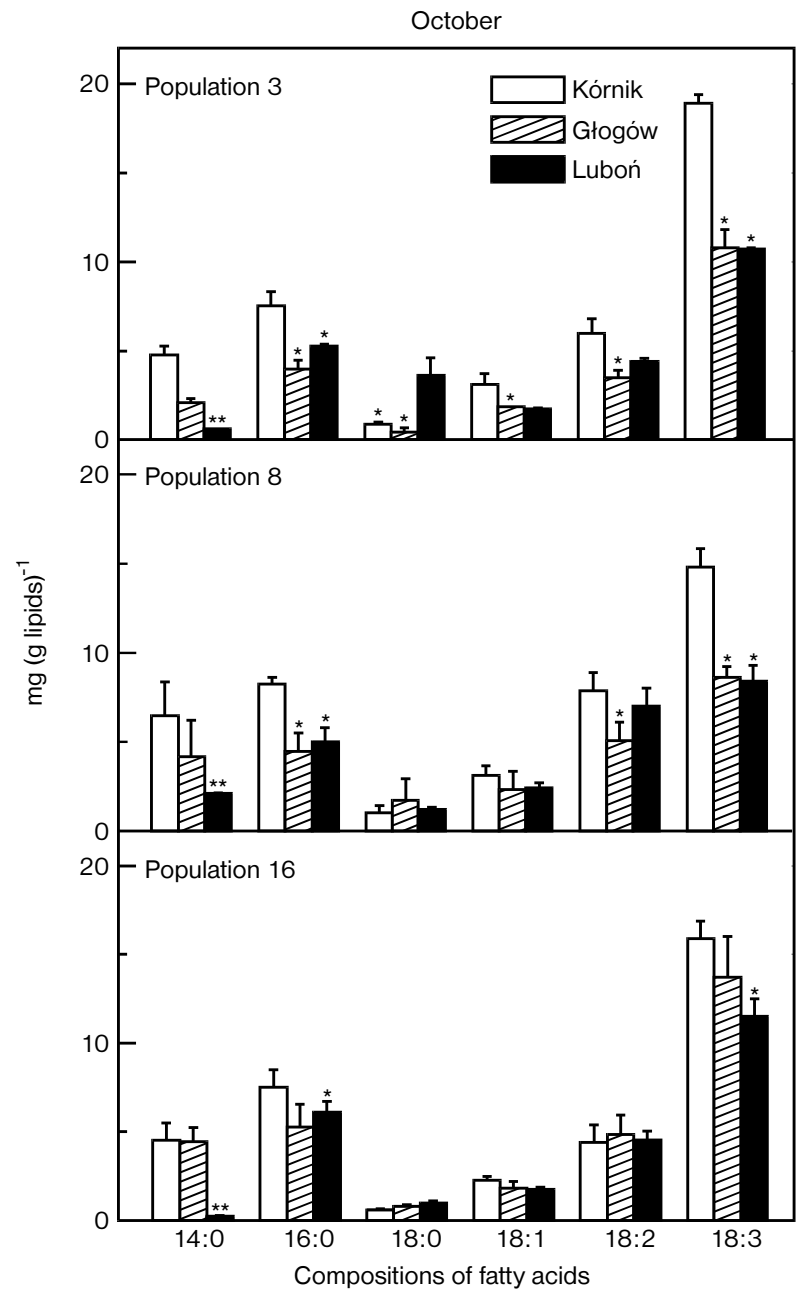

Fig. 2. Fatty acid composition of total phospholipids, in needles of three Scots pine populations of growing in Kórnik (control), Głogów and Luboń (polluted sites) at October. Values are means from three trees $(n=6)$ \pm SD. Mean values of significance between control and polluted, at $* P<0.05, * * P<0.01$.

Earlier research showed that the analysed provenances differ in sensitivity to unfavourable environmental conditions (Fober 1997). The pine trees deriving from Serebryanskoye and Zahorie proved to be more tolerant than the Polish population (Oleksyn et al. 1992). Our results indicate that under the influence of pollution, greater differences in cytoplasmic membranes can be observed in concentrations of individual fatty acids in needles of the studied pine trees (Figs 2 and 3). Except for data from June for pine trees growing at Głogów, in all other months of the study, the concentration of fatty acids in needles was markedly lower in the polluted habitat. However in autumn and winter, results of those analyses revealed increased differences. In all the populations studied, a clearly lower concentration of linolenic acid was observed in needles of trees growing on the plots at Luboń and Głogów (Figs 2 and 3).

On the other hand, it can be noticed that the two polluted habitats exerted a similar influence on the concentration and composition of lipids in cytoplasmic membranes in needles of the three populations of Scots pine. However, less drastic differences in total concentration of phospholipids in needles can be observed for the pine trees growing at Kórnik and Głogów. Similar tendencies of changes in composition of phospholipids and their fatty acids were obse-

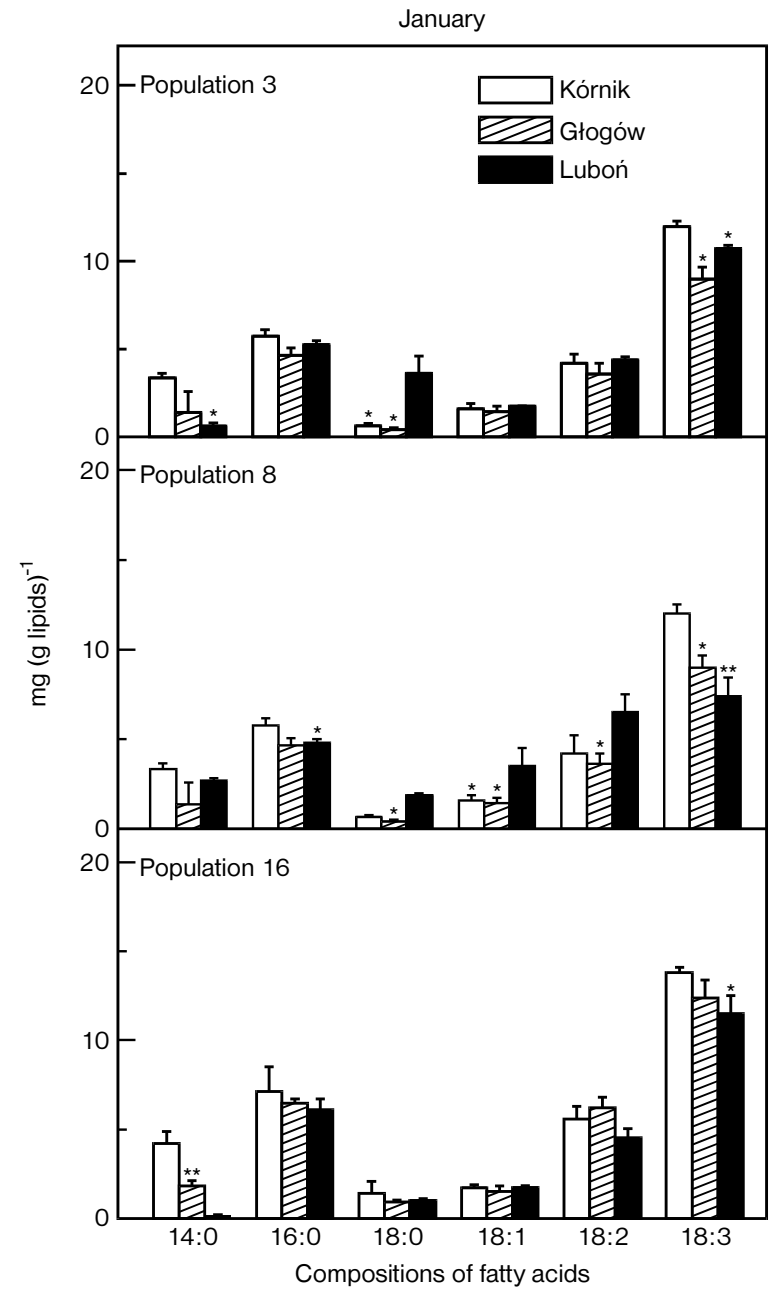

Fig. 3. Fatty acid composition of total phospholipids, in needles of three Scots pine populations growing in Kórnik (control), Głogów and Lubon (polluted sites) at January. Values are means from three trees $(n=6) \pm S$. Mean values of significance between control and polluted, at $* P<0.05$, $* * P<0.01$.

rved in roots of the studied pine populations (Pukacki and Kamińska-Rożek 2002). The present state of the trees at Głogów probably results from a marked limitation of industrial air pollution in that area. The small differences between the two plots in the case of Slovakian and Polish populations are consistent with results concerning changes in cytoplasmic membrane structure in pollen grains from these provenances (Pukacki and Chałupka 2003).

It can be concluded that concentrations of total phospholipids, individual phospholipids (especially PC) and polyunsaturated fatty acids are lower in pine needles from polluted habitats. The effect of provenance on changes in lipid structures of cytoplasmic membranes is less significant than the effect of pollution level. Unfavourable metabolic differences are greater in needles of the population of pine trees from the habitat polluted with sulphur, nitrogen and fluorine compounds (Luboń) than in tissues of pine trees originating from the habitat polluted with heavy metals and $\mathrm{SO}_{2}$ (Głogów). Significant differences in the lipid structure of membranes were observed mainly during winter dormancy. This state may be associated with a greater sensitivity of the studied organs of pine trees to negative effects of other abiotic factors such freezing dehydration or low temperature. 


\section{ACKNOWLEDGEMENTS}

I thank A. Górska and M. Matelska for technical assistance. This work was supported by the State Committee for Scientific Research (Poland) Grant No. 5 P06M 00909.

\section{LITERATURE CITED}

AMES D.N. 1966. Assay of inorganic phosphate, total phosphate and phosphatases. In: Methods in Enzym. (ed.), S.P. Colowick, N.O. Kaplan, Academic Press, NY, Vol. 8: 115-118.

ANONYMOUS. 1991. Industrial plants harmful for the environment. Aura 2 (1991): 14-15. (In Polish)

ANTTONEN S. 1992. Changes in lipids of Pinus sylvestris needles exposed to industrial air pollution. Ann. Bot. Fennici, 29: 89-99.

FOBER H. 1997. Effect of environmental pollution on the morphological characters of Scots pine (Pinus sylvestris L.). Arbor. Kornickie, 42: 199-215 (In Polish with English summary)

FREER-SMITH P.H., MANSFIELD T.A. 1987. The combined effects of low temperature and $\mathrm{SO}_{2}+\mathrm{NO}_{2}$ pollutionon the new season's growth and water relations of Picea sitchensis. New Phytol. 106: 237-250.

GIERTYCH M. 1993. Zmienność proweniencyjna. In: Biologia sosny zwyczajnej. (eds.) S. Białobok, A. Boratyński, W. Bugała. Sorus, Poznań-Kórnik. pp. 325-339. (In Polish).

JUANEDA P., ROCQUELIN G. 1985. Rapid and convenient separation of phospholipids and non phosphorus lipids from rat heart using silica cartridges. Lipids, 20: 40-41.

KENDALL E.J., MCKERSIE, B.D. 1989. Free radical and freezing injury to cell membranes of winter wheat. Physiol. Plant. 76: 86-94.

KNOP M., LUKASZEWICZ T., ANGELOW. Z. 1998. Automatische Immissionssysteme rings um die Betriebe KGHM Polska Miedź S.A. In: Rekultivierung und Umweltschutz in BergbauIndustriegebieten. Teil 1. (ed.) by TPN Legnica, pp. 273-251.

LESHEM Y.Y. 1992. Plant Membranes: A biophysical approach to structure, development and senescence. Kluwer Academic Publishers. pp. 1-266.

NICHOLS B.W., HARRIS R.V., JAMES A.T. 1965. The lipid metabolism of the blue-green alge. Biochim. Biophys. Res. Commun. 20: 256-262.

NILSSON S. 1991. European forest decline. In: The effects of air pollutants and suggested remedial policies. IISA Luxemburg, pp. 1-230.

OLEKSYN J., CHAŁUPKA W., TROELKER M.G., REICH P.B. 1992. Geographic origin of Pinus sylvestris populations influence the effects of air pollution on flowering and growth. Water Air Soil Pollut. 62: 201-212.

OLEKSYN J., REICH P.B., KAROLEWSKI P., TJOELKER M.G., CHAŁUPKA W. 1999. Nutritional status of pollen and needles of diverse Pinus sylvestris population grown at sites with contrasting pollution. Water Air Soil Pollut. 110: 195-212.

PRUS-GŁOWACKI W., WOJNICKA-PÓŁTORAK A., OLEKSYN J., REICH P.B. 1999. Industrial pollutants tend to in- creases genetic diversity: evidence from field-grown European Scots pine populations. Water Air Soil Pollut. 116: 395-402.

PUKACKA S., PUKACKI P.M. 2000a. Seasonal changes in antioxidant level of Scots pine (Pinus sylvestris L.) needles exposed to industrial pollution. I. Ascorbate and thiol content. Acta Physiol. Plant. 22: 451-456.

PUKACKA S., PUKACKI P.M. 2000b. Seasonal changes in antioxidant level of Scots pine (Pinus sylvestris L.) needles exposed to industrial pollution. II. Enzymatic scavengers activities. Acta Physiol. Plant. 22: 457-464.

PUKACKI P.M. 2000. Effects of sulphur, fluoride and heavy metal pollution on the chlorophyll fluorescence of Scots pine ( $P i$ nus sylvestris L.) needles. Dendrobiology, 45: 83-88.

PUKACKI P.M., CHAŁUPKA W. 2003. Environmental pollution changes in membrane lipids, antioxidants and vitality of Scots pine (Pinus sylvestris L.) pollen Acta Soc. Bot. Pol. 72: 99-144.

PUKACKI P.M., KAMIŃSKA-ROŻEK E. 2002. Long-term implications of industrial pollution stress on lipids composition in Scots pine (Pinus sylvestris L.) roots. Acta Physiol. Plant. 24: 249-255.

PUKACKI P.M., KAMIŃSKA-ROŻEK E. 2003. The role of antioxidant system in response to cold acclimation and freezing desiccation stress in Norway spruce seedlings. Free Radical Res., Supplement, 37(2), p. 44.

PUKACKI P.M., KENDALL E.J., MCKERSIE B.D. 1991. Membrane injury during freezing stress to winter wheat (Triticum aestivum L.) crowns. J. Plant Physiol. 138: 516-521.

REICH P.B., OLEKSYN J., TJOELKER M.G. 1994. Relationship of aluminium and calcium to net $\mathrm{CO}_{2}$ exchange among diverse Scots pine pronenances under pollution stress in Poland. Oecologia, 97: 87-92.

STRAND M. 1995. Persistent effect of low concentrations of $\mathrm{SO}_{2}$ and $\mathrm{NO}_{2}$ on photosynthesis in Scots pine (Pinus sylvestris) needles. Physiol. Plant. 95: 581-590.

SUTINEN M.-L., PALTA J.P., REICH P.B. 1992. Physiological changes in needles of Pinus nigra and Pinus resinosa with seasonal changes in freezing stress resistance: evaluation of the electrolyte leakage method. Tree Physiol. 11: 241-254.

TAULAVUORI K., TAULAVUORI E., NIINIMAA A., LAINE K. 1996. Frost resistance and $\mathrm{pH}$ of cell effusate in needles of artificially deacclimated Scots pine (Pinus sylvestris). Physiol. Plant. 96: 111-117.

TOMASZEWSKA B., TUKENDORFF A., BAREŁKIEWICZ D. 1996. The synthesis of phytochelatins in lupin roots treated with lead ions. The Sciences of Legumes, 3: 206-217.

WINGSLE G., HÄLLGREN J.-E. 1993. Influence of $\mathrm{SO}_{2}$ and $\mathrm{NO}_{2}$ exposure on glutathione superoxide dismutase and glutathione reductase activities in Scots pine needles. J. Exp. Bot. 44: 463-470.

ZWIAZEK J.J., SHAY J.M. 1988. The effect of sodium fluoride on cytoplasmic leakage and lipid and fatty acid composition of jack pine (Pinus banksiana) seedlings. Can. J. Bot. 66: 535-541.

YOSHIDA S., UEMURA M. 1990. Responses of the plasma membrane to cold acclimation and freezing stress. In: The Plant Plasma Membranes, Structure, Function and Molecular Biology, (eds) C. Larsson and I.M. Møller Springer-Verlag, Berlin-Heidelberg. pp. 293-319. 